\title{
Öğrenme Güçlüğünde Yazzlı Anlatımı Desteklemek: Strateji Öğretimi
}

\begin{tabular}{lccc}
\hline MAKALE TÜRÜ & Başvuru Tarihi & Kabul Tarihi & Yayım Tarihi \\
Derleme Makalesi & 12.01 .2021 & 21.09 .2021 & 04.10 .2021 \\
\hline
\end{tabular}

\author{
A. Bilal Özbek \\ Dokuz Eylül Üniversitesi
}

Burcu Kılıç Tülü

Ankara Üniversitesi

\section{Öz}

Yazılı anlatım, okuryazarlık gelişiminin önemli kazanımlarından birisidir. Yazılı anlatım sürecinde bireyin üretici konuma geçerek bilgisini, deneyimlerini ve hayal gücünü farklı metin yapılarına göre düzenlenmiş bir șekilde aktarması gerekmektedir. Bu süreçte birden çok bilișsel beceri etkin biçimde kullanılır. Öğrenme güçlüğü olan pek çok öğrenci yazılı anlatımda sorunlar yaşamaktadır. Alanyazında var olan araştırmalar ve uygulamalar incelendiğinde öğrenme güçlüğü olan öğrencilerin yazılı anlatım becerilerinin, okuma akıcıllı̆ğ ve okuduğunu anlama gibi akademik becerilerine göre daha az desteklendiği görülmektedir. Bu derleme çalışmasının amacı öğrenme güçlüğü olan öğrencilerin yazılı anlatım becerisinde yaşadıkları güçlükleri ve nedenlerini betimleyerek yazılı anlatım becerilerinin önemine dikkat çekmek ve desteklenmesine yönelik etkili bir yöntem olan strateji öğretimini örnekler ile açıklamaktır. Strateji öğretimi, yazılı anlatımın farklı aşamalarına ya da bütününe yönelik öğrencilerin planlama, yazma ve gözden geçirme aşamalarında becerilerini geliştirmeyi hedeflemektedir. Strateji öğretimleri, öğrenme güçlüğü olan çocuklar için açık bir şekilde model olunmasına ve sık tekrarlar yapılabilmesine olanak veren Kendini Düzenleme Stratejilerinin Gelişimi öğretim modeline göre yürütüldüğünde önemli kazanımların sağlandığı görülmektedir. Etkili bulunmuş stratejilerin öğretiminin yapılmasıyla ve yazma öncesi planlama, planları yazıya geçirme ve metni gözden geçirme așamalarının öğrencilere kazandırılması ile daha nitelikli yazılı ürünlerin oluşturması olanaklıdır. Bu çalışma ile ebeveynlerin, alanda çalışan öğretmen ve uzmanların öğrenme güçlüğü olan öğrencilerin yazılı anlatım becerilerinin desteklenmesine ilişkin farkındalıklarının arttırılması, bu konuda yapılacak uygulama ve araştırmalara katkı sağlanması amaçlanmıştır.

Anahtar sözcükler: Yazma, yazılı anlatım, strateji öğretimi, üştbilişsel strateji, öğrenme güçlügü.

Etik kurul kararı: Bu araştırma, derleme türünde makale olduğu için etik kurul kararı gerektirmemektedir.

${ }^{1}$ Sorumlu Yazar: Dr., Buca Eğitim Fakültesi, Özel Eğitim Bölümü, e-posta: bilal.ozbek@deu.edu.tr, https://orcid.org/0000-0002-0200-4932

${ }^{2}$ Dr., Eğitim Bilimleri Fakültesi, Özel Eğitim Bölümü, e-posta: burcukilic2012@hotmail.com, https://orcid.org/0000-0002-9623-8392 
Yazılı anlatım kişiler arasındaki iletişimin devamlılı̆̆ını sağlayan, insanların düşüncelerini etkileyen, birçok hedefi gerçekleştirmek ve öğrenmek için kullanılan vazgeçilmez bir araçtır (Bangert-Drowns, Hurley ve Wilkinson, 2004; Graham, 2006). Öğrenciler yazma becerisi ile kendi düşüncelerini ve deneyimlerini yansıtan ürünler ortaya koydukları gibi, edindikleri bilgiyi yapılandırmak, düzenlemek, yorumlamak ve hatırlamak amacıyla da bu beceriden yararlanmaktadırlar (Graham, Gillespie ve McKeown, 2013). Karmaşık bir beceri olarak tanımlanan yazılı anlatım, temel yazma becerilerinin, yazma akıcılığının, okuma akıcılığının, okuduğunu anlama becerilerinin, ön bilgi düzeyi, fikir üretme ve üretilen fikirlerin düzenlenmesi becerilerinin dahil olduğu bir süreçtir (Graham, 2006; Troia, Brehmer, Glause, Reichmuth ve Lawrence, 2020). Yazılı anlatım becerilerine sahip öğrencilerin farklı akademik alanlarda değerlendirmelerde daha iyi performans gösterebildikleri, 2-12. sınıflara devam eden öğrencilerin fikirlerini düzenleyerek metinler yazma, okudukları metinlere ilişkin özet yazma, not alma, sorular üretme ve bu soruları yanıtlama davranışlarının metni anlama becerilerini desteklediği belirlenmiştir (Graham ve Hebert, 2011). Aynı çalışmada yazmanın öğrencilerin akıcılık ve okuduğunu anlama becerileri üzerinde etkili olduğu görülmüştür. Yazılı anlatımın diğer akademik alanlara olan bu ilişkisine ek olarak, yazılı anlatım becerileri akademik başarıyı değerlendirmede de sık kullanılan bir araçtır (Graham, MacArthur ve Fitzgerald, 2007). Öğretim kademelerinin pek çok aşamasında öğrencilerin performansı açık uçlu sorularla değerlendirilir ve bu sorulara, öğrencilerin yazılı anlatım becerilerini kullanarak, bilgilerini düzenleyerek bütüncül yanıtlar vermeleri beklenir. Bu kapsamda da öğrencilerin yazılı anlatım becerilerinde gösterdikleri performans oldukça önemlidir.

Öğrencilerin akademik yaşamında son derece önemli olan yazma becerisinin gelişimi erken çocukluk döneminde karalamalarla başlamakta ve çocuk zamanla yazının bir işlevinin olduğunu fark etmektedir. Okulun ilk yılında ise okuma öğretimiyle birlikte çocukların ses, hece, sözcük, cümle ve ardından metin yazma becerileri gelişmektedir (Abbott, Berninger ve Fayol, 2010). Yazının fiziksel üretimiyle ilgili olan yazmanın mekanik boyutunda öğrencilerin ustalaşmaları el göz koordinasyonu, küçük kas gelişimi gibi becerileri ile ilişkilidir. Öğrencilerin zaman içerisinde bakarak kopya etmeden, söylenilen cümleleri bağımsız olarak dikte etmeye kadar yazmanın mekanik boyutunda ustalaşmaları gerekmektedir. Öğrenciler yazma becerisinde ustalaştıkça uygun hızda ve okunaklı yazma olarak tanımlanan yazma akıcılığ doğruluğu okulun ilk yıllarında ögrencilerden beklenen temel yazma becerisidir (Berninger ve diğ., 2006). Yazılı anlatım ise hızlı ve doğru yazma becerileri ile birlikte pek çok farklı becerinin de kullanıldığı daha karmaşık bir beceridir.

Öğretim programı incelendiğide yazılı anlatım, özellikle üçüncü sınıf ve sonrası dönemde öğrenciler bilgilerini, düşüncelerini ve deneyimlerini aktarmak için yazma becerisini bir araç olarak kullanmaya başladıklarında önem kazanmaktadır. Milli Eğitim Bakanlığı (MEB) öğretim programının ilkokul ve ortaokul düzeyindeki kazanımlarında öğrencilerin yazım, noktalama, dilbilgisi kurallarına uygun olarak 
belirli bir amaç ve okuyucu kitlesine göre ve farklı türlerde yazılı ürünler oluşturmaları beklenmektedir (MEB, 2019). Gerek öğretim programında yer alan yazma becerilerine ilişkin amaçların değerlendirilmesinde gerekse diğer derslerin sınavlarında öğrencilerin yazılı anlatım becerilerini etkin biçimde kullanmaları gerekmektedir. Bu değerlendirmelerde tipik gelişen öğrencilerin bir bölümüöğrenme güçlüğü olan öğrencilerin ise neredeyse tamamı sorunlar yaşayabilmektedirler (Graham, Collins ve Rigby-Wills, 2017). Ulusal Eğitsel İlerleme Değerlendirmesi (National Assessment of Educational Progress-NAEP) raporuna göre öğrenme güçlüğü olan öğrencilerin yalnızca \%6'sı yeterli yazma becerilerine sahiptir (Graham ve Perin, 2007). Buna karşın pek çok eğitimcinin öğrencilerin yazma becerilerini desteklemek için kullandığı zaman ile öğretim programında yazılı anlatıma verilen önem arasında bir tutarsızlık bulunmaktadır (Graham ve Harris, 1997). Özellikle okuma akıcılı̆̆ ve okuduğunu anlama becerilerinin desteklenmesine ayırılan zaman arttıkça yazma becerileri öğretim odağından uzaklaşmakta ve bu beceriye daha az zaman ayrılmaktadır (Baker, Gersten ve Graham 2003). Bu durum hem yazilı anlatımda sorun yaşayan öğrenciler hem de öğrenme güçlüğü olan öğrenciler için ciddi bir sınırlılı̆̆a (dezavantaja) dönüşmektedir.

Öğrenme güçlüğü olan öğrencilerin varolan yazılı anlatım sorunlarına bakıldığında, bu çocukların akranlarına göre uzun bir yazılı ürün üretme, metin oluşturma, uygun noktalama işaretlerini kullanma, yazma sürecini anlama ve kendi yazma yeteneklerine ilişkin algıları dahil olmak üzere yazmanın birçok yönüne ilişkin daha fazla sorun yaşadığı görülmektedir (Graham ve Harris, 1992; Troia, 2006). Bu öğrenciler ayrıca metin yapısını belirlemekte ve farklı metin yapılarına uygun yazmakta, özelikle farklı türleri olan bilgilendirici metinler (karşılaştırma, zamansal, tanımlayıcı, problem-çözüm vb.) yazmak (Dymock, 2005) için desteğe gereksinim duymaktadırlar (Gersten ve Baker, 2001; Williams, Hall ve Lauer, 2004). İyi düzenlenmiş nitelikli bir yazılı ürünü ortaya koymak öğrenilebilir bir beceridir ve bu beceriyi desteklemek için etkili yöntemlerin kullanılması gerekmektedir. Bu derleme kapsamında da öğrenme güçlüğü olan öğrencilerin yazılı anlatım becerilerinin desteklenmesinde kullanılan stratejiler örneklerle açıklanmaktadır. Öğrenme güçlüğü olan öğrencilerin yazılı anlatım becerilerine müdahale etmek için öncelikle bu beceriyi oluşturan bileşenlerden ve iyi bir yazılı anlatımın gerekliliklerinden söz etmek gerekmektedir.

\section{Yazılı Anlatımın Aşamaları}

Yazılı anlatımın oldukça karmaşık bir süreç içermesi bu sürecin açıklanmasında farklı görüşlerin oluşmasına neden olmuştur (Graham, McKeown, Kiuhara ve Harris, 2012). Yazılı anlatım sürecinin nasıl şekillendiğini açıklamaya yönelik iki temel görüş̧ bulunmaktadır. Bunlardan ilki yazılı anlatımınnasıl şekillendiğini açıklamada bilişsel süreçlere ve yazmaya ilişkin güdülenmeyeodaklanırken (Hayes, 1996); ikincisi metin yapıları bağlamında yazılı anlatımı şekillendirmesine odaklanmaktadır (Russell, 1997). Bütüncül olarak bakıldığında, yazma sürecinin başarılı bir şekilde yönetilmesi üzerinde uygun yazma ortamı, ne hakkında yazıldığı, yazarın amacı, yazarın yazma için gerekli bilgi, beceri ve stratejilere sahip olması gibi etkenler etkili olmaktadır 
(Zimmerman ve Risemberg, 1997). Berninger ve Amtmann (2003) ise yazı anlatım sürecini, yazım ve yazının mekanik yönünü ve kendini düzenleme, planlama, gözden geçirme ve düzenlemeyi de içeren yürütme işlevi olmak üzere iki etken ile açıklamaktadır. Bu derleme makalesi kapsamında ilkokul ve ortaokul düzeyinde temel yazılı anlatım becerilerine yönelik strateji öğretimine odaklanılması nedeniyle yazma becerisi süreçte gösterilmesi gereken davranışlar (planlama/yazma/gözden geçirme) bakımından ele alınmıştır. Bununla birlikte strateji öğretiminin farklı metin türlerini tanıma ve bu metin türlerine uygun yazılar yazmakta önemli katkılar sağladığı bilinmektedir (Pyle ve diğ., 2017).

Yazılı anlatım temel olarak planlama, planların yazıya aktarılması ve yazılan metnin gözden geçirilerek kontrol edilmesi olmak üzere üç aşamadan oluşmaktadır (Hayes ve Flower, 1980). Yazma sürecinin ilk aşamasında öncelikle öğrencilerin hakkında yazılan konu üzerine düşünmeleri, fikirler üreterek bu fikirlerini düzenlemesi için uygun sürede planlama yapmaları gerekir. Planlama, yazma amacı belirleme, fikir üretme ve fikirlerin düzenlenmesini içerir ve yazılı anlatımda başarılı olanlar bu süreci iyi bir şekilde yöneterek yazma öncesinde yoğun bir şekilde çalışırlar (Graham ve Harris, 2003). Planlama ile metinlerin organizasyonu ve konunun farklı boyutlarının aktarılması daha kolay olmaktadır. Yazma sürecinin başında iyi bir planlama yapıldığında daha nitelikli yazılı anlatım ürünleri ortaya çıkmaktadır (Chalk, Hagan-Burke, ve Burke, 2005; Thoennes, 2016). Ek olarak, bu planlamalar metin türlerine göre de farklılıklar göstermektedir (Pyle ve diğ., 2017).

Planlamanın ardından üretilen fikirlerin uygun sırada ve bir bütünlük içerisinde metne dönüştürüldüğü yazma süreci başlamaktadır. Yapılan planlama sonucunda üretilen fikirlerin yazma aşamasına aktarılmasında paragrafların bütünlük içerisinde, ilişkileri yansıtacak şekilde oluşturulması ve yazılmakta olan metin türünün özelliklerini yansıtan ve bilgileri birbiriyle bağlayan anahtar sözcüklerin kullanılması önemlidir. Bu anahtar sözcükler ile anlatımın ve fikirlerin daha iyi aktarılması, cümlelerin birbirine bağlanması ve anlamsal bütünlüğün sağlanması olanaklı olmaktadır. Yazılı anlatım sürecinde planlama ve planların metne dönüştürülmesi kadar önemli olan son aşama oluşturulan metnin gözden geçirilerek kontrol edilmesidir (Wong, Butler, Ficzere ve Kuperis, 1996).

İyi yazılmış bir metnin ilk denemede başarılı bir şekilde oluşturulmasının zor olduğu düşünülmektedir. Yapılması muhtemel olan yazım yanlışı gibi basit hataları, sözcük seçimlerini, anlatım bütünlügünü daha iyi yansıtmak için metin yapısına uygun şekilde kullanılan ve metindeki bilgileri birbirine bağlayan anahtar sözcük (örneğin bu nedenle, bundan sonra, ancak vb.) kullanımlarını metni tekrar okuyarak gözden geçirerek kontrol etmek yazılı anlatımın niteliğini arttırmaktadır. Görüldüğü üzere yazılı anlatım içerisinde birçok farklı beceriyi içeren ve öğrencilerin ön bilgilerinin önemli olduğu karmaşık bir süreçtir. Bu karmaşık sürecin her öğrenci tarafından başarılı bir şekilde yönetilebilmesi olanaklı olmamaktadır. 


\section{Öğrenme Güçlüğü ve Yazılı Anlatım}

Alanyazında öğrenme güçlüğü olan öğrencilerin iyi bir yazılı ürün ortaya koymak için gerekli bilgi ve beceride sınırlılıklar yaşadıkları belirtilmektedir (MacArthur, 2007; MacArthur, Graham ve Schwartz, 1991). Bu öğrencilerin tipik gelişen akranlarıyla karşılaştırıldığı çalışmalarda öğrenme güçlüğü olan öğrencilerin yazma becerilerinde daha yoğun güçlükler yaşadıkları görülmektedir (Graham, Schwartz ve MacArthur, 1993; Reid ve Lienemann, 2006; Thoennes, 2016). Yakın tarihli bir meta-analiz çalışmasında, öğrenme güçlüğü olan öğrencilerin yazı niteliği, planlama, sözcük bilgisi, cümle akıcılı̆̆ı, yazım kuralları, dilbilgisi, el yazısı ve güdüleme (motivasyon) açısından tipik gelişen akranlarına göre daha çok zorlandıkları belirlenmiş̧ir (Graham, Fishman, Reid ve Hebert, 2016; Öztürk ve Girli, 2018). Öğrenme güçlüğü olan öğrenciler başarılı bir yazılı anlatım için gereken planlama yapma, fikir üretme ve fikirleri düzenlemeile yakından ilişkili esnek düşünme, farklı bakış açılarını görebilme, kendi fikirlerini destekleyebilen nedenler üretme ve süreç boyunca kendini düzenleme becerilerinde de akranlarındandaha fazla güçlük yaşamaktadırlar (Hooper, Swartz, Wakely, de Kruif ve Montgomery, 2002; Öztürk ve Girli, 2017). Bunların bir sonucu olarak yazılarının yazma amacına uygunluğu ve ilgi çekiciliği oldukça düşüktür. Sonuç olarak, yazma performansını etkileyen okuma, yazma gibi farklı alanlarda öğrenme güçlüğü olan öğrenciler tipik gelişen akranlarından daha yetersiz performans göstermektedirler (Gersten ve Baker, 2001).

Öğrenme güçlüğü olan öğrencilerin yazılı anlatımda başarılı olan akranlarına göre yazma sürecinin aşamalarında farklı özellikler gösterdikleri, planlama aşaması açısından yazmaya başlamadan önce yönerge verildiğinde dahi bir dakikadan az planlama yaptıkları, fikirleri düzenlemede güçlük çektikleri ve yazma sürecini desteklemede yetersiz planlar ortaya koydukları belirtilmektedir (Graham ve dĭg., 2017; MacArthur ve Graham, 1987). Yazma sürecine iyi bir planlama olmadan başlamaları nedeniyle kısa metinler yazdıkları ve yazma sürecini oldukça hızlı sonlandırdıkları görülmektedir (Graham, 1990). Bazı öğrenciler planlama yapsa dahi, doğru yazma, noktalama işaretleri gibi yazmanın mekanik yönüne çok fazla süre harcadıkları için planladıklarını unutmaktadır (Graham, Harris ve Fink, 2000). Aynı zamanda yazmaları gereken metne ilişkin fikir üretseler bile bu fikirleri metne dönüştürmek için gerekli strateji becerilerine sahip olmamaları yazdıkları metinlerin kapsam1, niteliği ve bütünlüğünü etkilmektedir (Englert ve Raphael, 1988; Montague, Graves ve Leavell, 1991). Ek olarak, öğrenme güçlüğü olan öğrencilerin genellikle basit ve kısa cümleler ile yazılarını oluşturdukları ve metni oluştururken kullandıkları farklı sözcük sayılarının da oldukça az olduğu bilinmektedir (Graham ve diğ., 2000). $\mathrm{Bu}$ öğrenciler metni gözden geçirme aşamasında ise isteksiz olmakta, çoğunlukla metni gözden geçirmemekte, gözden geçirdiklerinde ise sadece biçimsel hatalarını düzeltmeye yönelik girişimlerde bulunmaktadırlar (Reid ve Lienemann, 2006). Bu güçlükler motivasyonlarının düşmesine ve yazmaya ilişkin olumsuz tutum geliştirmelerine neden olmaktadır (Troia, Harbaugh, Shankland, Wolbers ve Lawrence, 2017). Bu ise yazma girişimlerinin ve yazma becerilerini geliştirme 
firsatlarının azalması ile sonuçlanmaktadır (Harris ve Graham, 2013). Oysa iyi bir yazar olmak için öğrencilerin farklı amaçlar için sık sık yazmaları gerekmektedir (Graham ve diğ., 2012). Bu şekilde oluşan bir döngünün tersine çevrilmesi amaciyla öğrenme güçlüğü olan öğrencilerin yazılı anlatım performanslarının geliştirilmesine yönelik müdahale çalışmalarının yapılması son derece önemlidir.

\section{Öğrenme Güçlüğü Olan Öğrencilerin Yazılı Anlatım Becerilerinin Strateji Öğretimiyle Desteklenmesi}

Yazılı anlatım becerilerinin geliştirilmesi hedeflenen bir öğrenci için sosyal etkileşim gereksinimlerine uygun yanıt verebilen bir öğretmen ya da yetişkin ile çalışmak, öğrencileri çeşitli yazı biçimleriyle tanıştırmak, öğrencilerin dil gelişimlerini desteklemek ve yazma deneyimleri kazanmaları için firsatlar sunarak yazma gelişimlerine katkıda bulunmak gerekmektedir (Graham ve Perin, 2007). Bu bağlamda öğrencinin ilgi alanlarının ve üzerine konuşmaya istekli olduğu, hakkında bilgi sahibi olduğu konuların yazma çalışmalarına konu edilmesi önemlidir (Troia ve diğ., 2017).

Öğrencilerin yazılı anlatım becerilerine yönelik olarak öğretmenlerin açık anlatım ile sözel yönergeler verdikleri, iyi yazılmış bir metnin özelliklerini açıklama gibi yollardan yararlandıkları, öğretmen merkezli uygulamalar yürüttükleri ve sıklıkla öğrencilerin ürünlerini değerlendirirken yazım hataları ve dil bilgisi kuralları gibi biçimsel özellikler üzerinde durdukları görülmektedir (Dockrell, Marshall ve Wyse, 2016; Seban, 2008). Ancak öğrenme güçlüğü olan öğrencilerin daha açık öğretim yöntemlerine gereksinimleri vardır ve bu uygulamalar öğrenme güçlüğü olan öğrencilerin yazılı anlatım becerilerini belli bir noktaya kadar desteklemektedir. Bu nedenle yapılacak çalışmalarda öğrencilerin performanslarının devamlılığını sağlayan, edindikleri becerileri başka durumlara uyarlamalarına yardımcı olan yöntemler kullanılmalıdır (Graham ve Harris, 2003). Yapılan meta-analiz çalışmalarında araştırmacılar farklı sınıf düzeylerinden öğrencilerin yazılı ürünlerinin niteliğinin arttırılmasında etkili olan bazı yöntemleri ve bileşenleri belirlemişlerdir. Bunlar, strateji öğretimi, işbirlikli yazma, yazma öncesi hazırlıklar, özetleme, cümle yapılarını uzatma, metin yapısı öğretimi, dikte becerilerinin öğretimi, yazmayı değerlendirme ve ek yazma süresi sağlama gibi yöntemlerdir (Bangert-Drowns, ve diğ., 2004; Graham ve Perin, 2007). Bu yöntemlerden biri olan strateji öğretimi farklı metin yapılarına yönelik, yazma sürecinin planlama, yazma ya da gözden geçirme aşamalarında öğrencilerin göstermeleri gereken davranışların öğretilmesini hedefleyen ve öğrenme güçlüğü olan öğrencilerle sıklıkla kullanılan etkili bir yöntemdir (Harris, Graham, Friedlander ve Laud, 2013). Yazma startejilerini bütüncül bir şekilde yürütmek ve bağımsız kullanabilmek öğrenme güçlüğü olan öğrencilerin en temel sorunlarından biridir ve bu sorunu çözmek için öğrenme güçlüğü olan öğrenciler çevresel ve sosyal desteğe gereksinim duymaktadırlar (Cameron, Hunt ve Linton, 1996). Son yıllarda öğrenme güçlüğü olan öğrencilerin yazıllı anlatım becerilerinin geliştirilmesine yönelik strateji öğretimini temel alan çalışmaların yaygın olduğu görülmektedir (Berry ve Mason, 2012; Evmenova, Regan, Ahn ve Good, 2020; Ö̈zbek, Kılıç-Tülü ve Ergül, 2019). Bu öğretimler farklı sinıf 
düzeylerinde, çeşitli tanı gruplarında ve farklı metin türlerinde kullanılmaktadır (Güzel-Özmen, 2006a; Güzel-Özmen, 2006b; Özmen, Selimoğlu ve Şimşek, 2015; Shen ve Troia, 2018). Strateji öğretiminde öğrencinin metni oluştururken neler yapması gerektiğini adım adım anlatan hatırlatıcı kısaltmalar ve fikirlerini düzenlemelerini sağlayan şemalar ile sözcük kartları gibi işlemsel kolaylaştıııcılar kullanılarak öğrencilere daha nitelikli metinler yazabilmeleri için planlama, fikir üretme, fikirleri düzenleme, paragraf oluşturma, yazdıklarını kontrol etme ve düzeltmeler yapma gibi becerilerin kazandırılması ve öğrencilerin stratejilerin kullanımlarını içselleştirmeleri hedeflenmektedir. Öğretmen rehberliğinde öğrenciyi etkin kılan strateji öğretimine yönelik bu müdahalelerin öğrencilerin yazma becerilerinin gelişiminde etkili olduğu görülmektedir (Graham ve Hebert, 2010).

Alanyazındaki strateji öğretimi çalışmaları incelendiğinde planlama, yazma ve gözden geçirme aşamalarının tümünü kapsayan bütüncül öğretimler olduğu gibi yazmanın bir veya iki aşamasına odaklanan süreç temelli strateji öğretimlerinin de bulunduğu görülmektedir. Yazılı anlatım sürecini bütüncül olarak ele alan öğretime Englert, Raphael, Anderson, Anthony ve Stevens (1991) tarafindan ortaya konulan POWER (plan-planlama, organize-düzenleme, write-taslak oluşturma, edit-düzeltme, revise-gözden geçirme) modeli örnek olarak verilebilir. Bu modelde her bir harf öğrencilere yazma sürecinde yapmaları gereken bir işe ipucu vermektedir ve süreç yazılı anlatımın planlama, yazma ve gözden geçirme basamaklarının tümünü içermektedir. Yazma sürecinin bütüncül olarak öğretildiği bir diğer stratejiye PLANS (Pick goals-amaçlarını seç, List ways to meet goals-amaç-alt amaçları belirle, and make notes-notlar al fikir üret, sequence notes-notlarını ve fikirlerini sırala) (Mason, Snyder, Sukhram ve Kedem, 2006) stratejisi örnek olarak verilebilir.

Yazılı anlatımın bir ya da iki aşamasına odaklanan süreç temelli strateji öğretimlerine STOP and LIST (stop-dur, think of purpose-amaçlarını düşün, list ideas-fikirlerini listele ve sequence them-sirala; Graham ve Harris, 2005a; Özbek ve diğ., 2019), STOP and DARE (suspend judgment-yargıya ulaşmak için bekle, take a side-bir taraf seç, organize ideas-fikirlerini düzenle, plan more as you write-yazarken daha fazla plan yap, develop a position statement-konu cümleni geliştir, add supporting ideas-destekleyici fikirler ekle, report and refute counter arguments-diğer tarafın dayanaklarını çürüt, end with a strong conclusion- güçlü bir sonuç cümlesiyle bitir; Ennis, Jolivette ve Boden, 2013), POW and TREE (pick my ideas-bir fikir seç, organize my notes- notlarını düzenle, write and say more-daha fazla yaz ve söyle, topic sentence-neye inandığını söyle, reasons-buna niçin inanıyorsun?, endingsonuçlandır, examine-nedenlerini açıkla; Berry ve Mason, 2012), PLEASE (Pickfikirlerini seç, list-listele, evaluate-değerlendir, activate-etkinleştir, suply-oluştur, end-sonlandır; Welch, 1992) örnek olarak verilebilir. Bu stratejilerin pek çoğunun ortak noktası planlama aşamasını içermeleridir. Bu strateji örneklerinde tanımlayıcı bir metin yazarken kullanılabilecek planlama kağıtlarına bir örnek Şekil 1'de verilmiştir. 


\section{Şekil 1}

Planlama Kă̆ıdı Örneği

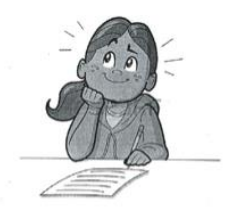

Ne hakkında yazıyorum?

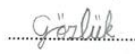

Nedir?

Kimdir?

Nerede?

Nasıl?

Niye?

Kaç?

Özellikleri neler?

Hangi özelligi??

Niçin?

Cescithen

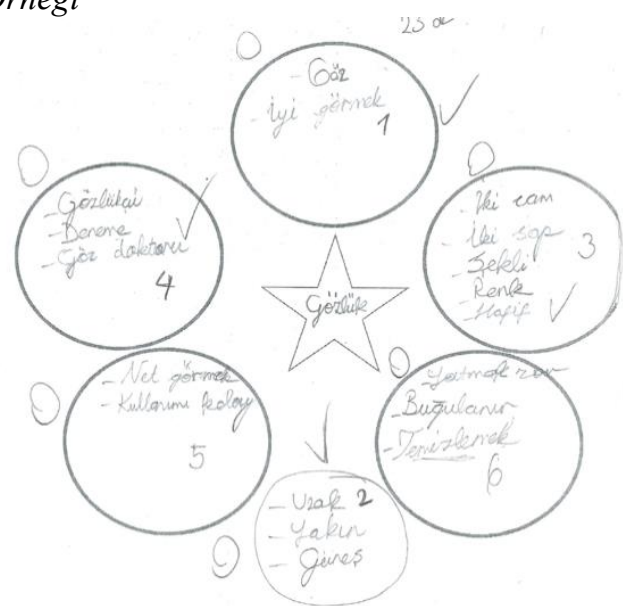

Şekil 1'de tanımlayıcı bir metin yazarken öğrencilerin iyi bir planlama yapmak için doğru soruları sormalarına ve bilgileri düzenlemelerine yardımcı olan bir planlama kağıdı görülmektedir. Öğrencilerin ürettikleri fikirleri ilişkili yerlere yazarak böylece metin organizasyonu ve anlam bütünlüğü olan paragraflar yazmaları hedeflenmektedir. Çalışma kağıtları öğrencilere ipuçları sunarak yazma sürecinde destekler sağlar. Şekil 2'de ise öğrencilerin bilgi birimleri arasında bağlayıcı olarak kullanmalarına ve tanımlayıcı metin yapısına yönelik anahtar sözcük örnekleri içeren çalışma kağıdı örneği yer almaktadır.

\section{Şekil 2}

Çalışma Kă̆ıldı Örnĕ̆i

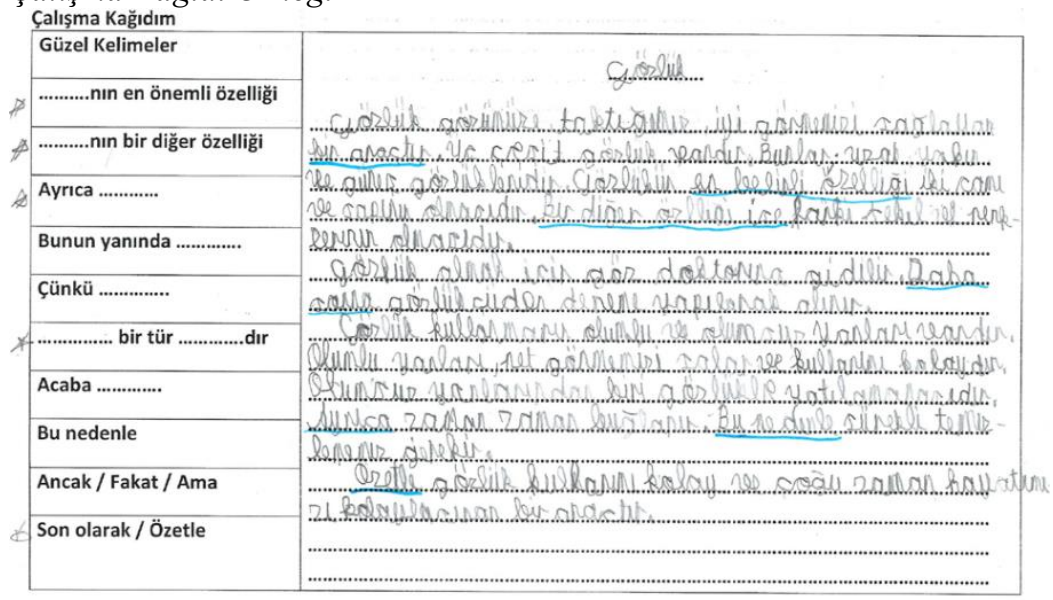


Çalışma kağıdındaki anahtar sözcükleri öğrencilerin kullanmaları sağlanarak metnin anlam bütünlüğünün arttırılması hedeflenmektedir. $\mathrm{Bu}$ sözcükler metin yapılarına göre (karşılaştırma, neden-sonuç, problem çözüm) farklılaşan ve yazarın düşüncelerini, planlama aşamasında ürettiği fikirleri bir bütünlük ve bağdaşıklık içerisinde yazabilmesini sağlar.

Yazma sürecinin bütüncül olarak ele alınmadığı yazılı ifade strateji öğretimi çalışmalarının pek çoğunun Kendini Düzenleme Stratejilerinin Gelişimi-KDSG (Self Regulation Strategies Development-SRSD) (Graham ve Harris, 2003) strateji öğretim modeli temel alınarak yürütüldüğü görülmektedir. KDSG modeli öğrenme güçlüğü olan öğrencilerin motivasyonlarını, bilişsel ve akademik özelliklerini göz önünde bulunduran bir strateji öğretimi sürecidir (Graham ve Harris, 2003). KDSG modelinde öğrencilere yazma stratejileri ve bu stratejileri kullanmak için gerekli bilgi ve beceriler öğretilmektedir. Öğrenci öğrenme sürecinde etkindir. Öğretim sırasında sağlanan geribildirimin ve öğretim desteğinin türü ve düzeyi, öğrencilerin gereksinimlerine yanıt verecek şekilde ayarlanır ve strateji kullanımının sorumluluğu aşamalı olarak öğretmenden öğrenciye aktarılır. Öğretim, öğrencinin bilişsel, duygusal ve davranışsal özelliklerine göre uyarlanabilir. Dolayısıyla her öğrenci kendi hızında ilerler ve her bir aşamada beklenen ölçütler karşılandığında bir sonraki aşamaya geçilir.

KDSG modelinin aşamaları önbilgilerin geliştirilmesi, tartışma, model olma, ezberleme, destekleme ve bağımsız uygulamalardır (Reid ve Lienemann, 2006). İlk aşamada öğrencinin çalışılan beceriye ilişkin ön bilgileri etkin duruma getirilir ve deneyimleri öğrenilir. Öğrencilerin o ana kadar herhangi bir yazma deneyiminin ve ön bilgisinin olmaması önemli değildir. Karşılıklı sohbet içerisinde öğrenciye metinlerin nasıl yazıldığı, bir metnin iyi yazılmış olduğunu gösteren ölçütleri örnekler üzerinde açıklayarak ön bilgileri uygulamacı sağlayabilir. İkinci aşama olan tartışma aşamasında öğrenilecek olan stratejinin ve becerinin önemi üzerine öğrenciyle konuşulur. Üçüncü aşama olan model olma aşaması ise öğrenci ile etkin bir şekilde çalışılarak stratejinin kullanımına model olunduğu bölümdür. Dördüncü aşama olan ezberleme aşaması her zaman kullanılmamakla birlikte öğretilen stratejinin basamaklarının öğrenci tarafından ezberlenmesini içermektedir. Öğrenci model olma aşamasında belirlenmiş olan başarı ölçütünü karşıladıktan sonra beşinci aşama olan desteklemeye geçilir. Bu aşamada uygulamacı aşamalı olarak rolünü öğrenciye devrederek ipuçlarını geri çeker ve öğrenciyi bağımsızlaşmaya hazırlar. KDSG öğretim modeli altıncı ve son aşama olan öğrenciye yalnızca yönerge verilerek öğretilen stratejiyi kullanmasının beklendiği bağımsız uygulamalar oturumları ile sona erer. Bu oturumlarda uygulamacı gerekli durumlarda öğrenciye ipuçları vererek sürece devam etmesini sağlar. Eğer öğrenci bir aşamada beklenenin altında performans gösteriyorsa o aşamaya ayrılan süre uzatılabilir ve öğrenci beklenen performansı gösterene kadar bir sonraki aşamaya geçilmez (Reid ve Lienemann, 2006). SSekil 3 'te KDSG öğretim modeline göre yürütülecek bir strateji öğretimi şemalaştırılmıştır. Bu şemanın ayrıntılı anlatımı ise Ek bölümünde verilmiştir. 


\section{Şekil 3}

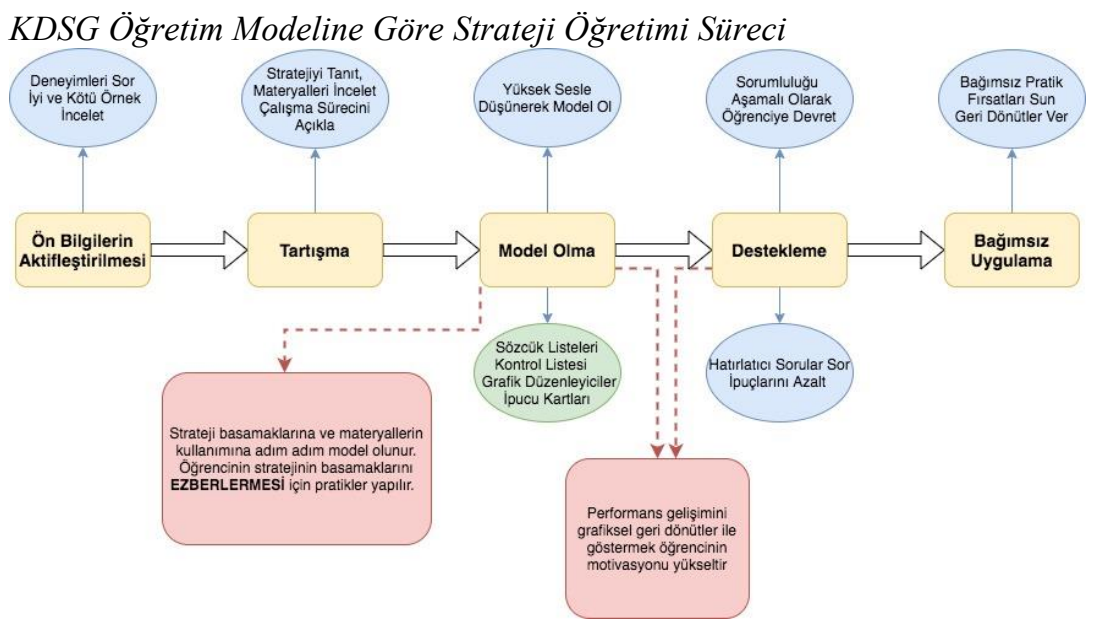

İyi bir öğretim modelinin etkili, sistematik, zaman ve enerji açısından ekonomik olması gerektiğini belirten Harris, Graham ve Mason (2003), bir stratejinin öğretimi için 30-40 dakika süren toplam 8-12 oturumluk bir sürecin öğrencilerin KDSG sürecinin aşamalarını tamamlamaları için yeterli olduğunu belirtmiştir. Yazma açısından KDSG modeline göre yürütülen öğretimlerin amacı öğrencilerin yazmaya ilişkin bilgilerini, stratejik yazma süreçlerini ve yazmaya karşı olan motivasyonlarını arttırmaktır (Graham ve Harris, 2005b). Yazılı anlatımın KDSG modeline göre öğretildiği araştırmalarda hatırlatıcı ipuçlarının kullanılması, kullanılan stratejilerin kalıcılığını arttırmakta ve öğrencilerin performanslarını geliştirmektedir (Saddler, 2006). Öğrencilerin strateji kullanmaları plan yapmak ve bu planları yazıya aktarmak için daha fazla zaman ayırabilmelerine, dolayısıyla yazdıkları metinlerin uzunluğunun ve yazılı ürünlerinin niteliğinin artmasına katkı sağlamaktadır (Berry ve Mason; 2012; De La Paz, 1999; Harris, Graham ve Mason, 2006; Özbek ve diğ., 2019). Yazılı anlatım araştırmalarının sonuçlarının incelendiği meta analiz çalışmalarında KDSG modeline göre yürütülen strateji öğretiminin yazılı anlatım üzerinde etkisinin oldukça büyük olduğu belirtilmektedir (Gillespie ve Graham, 2014; Graham ve diğ., 2016; Graham ve Perin, 2007; Taft ve Mason, 2011). MacArthur ve Philippakos, (2010) 11 14 yaşları arasında öğrenme güçlüğü tanısı almış üç öğrenci ve ortalama başarı gösteren üç tipik gelişim gösteren akran ile yürüttükleri araştırmalarında öğrencilerin karşılaştırma metni yazma performanslarını metin yapısı öğeleri, nitelik, uzunluk değişkenleri bakımından geliştirmeyi hedeflemişlerdir. Planlama, yazma ve gözden geçirme aşamalarına yönelik bütüncül bir strateji öğretiminin yapıldığı araştırma sonunda öğrencilerin yazılı anlatım performanslarında tüm değişkenler açısından artışların gözlendiği ve öğrencilerin strateji öğretimine yönelik olumlu görüşler belirttikleri ifade edilmişstir. 
Gersten ve Baker (2001), öğrenme güçlüğü olan öğrencilerin yazılı anlatım becerilerini desteklemeye yönelik yapılmış 13 deneysel ve yarı deneysel müdahaleleri içeren bir meta-analiz çalışması gerçekleştirmiş̧ir. Yaptıkları analizlerde, özellikle yazma sürecinde kullanılan öğretimlerin etkilerine odaklanmışlardır. Sonuçlara göre strateji öğretimi ile öğrenme güçlüğü olan öğrencilerin yazma niteliğinde önemli gelişmeler sağlanmaktadır. Tek denekli deneysel çalışmalar analizlere dahil edilmemiş olsa da bu araştırmaların sonuçlarının da strateji öğretiminin öğrenme güçlüğü olan öğrencilerin yazma becerilerini olumlu etkilediği sonucunu desteklediği araştırmacılar tarafindan belirtilmiştir. Ek bölümünde KDSG öğretim modeline göre hazırlanmış dokuz oturumdan oluşan yazılı anlatım becerilerine yönelik strateji öğretimine örnek verilmiştir.

Ulusal alanyazın özel gereksinimli bireylere yazılı anlatım stratejilerinin öğretimi açısından incelendiğinde zihinsel yetersizliği olan öğrenciler ile yapılmış olan araştırmalar dikkati çekmektedir. Güzel-Özmen'in (2006a) uyarlanmış bilişsel strateji öğretiminin hafif düzeyde zihinsel yetersizliği olan öğrencilerin yazılı anlatım becerileri üzerinde etkili olduğu sonucuna ulaştığı çalışması ile zihinsel engelli bir öğrenciye öykü yazma becerilerinin öğretiminde uyarlanmış bilişsel strateji öğretiminin etkili bulunduğu (Özmen ve diğ., 2015) iki önemli araştırma ön plana çıkmaktadır. Ayrıca Güzel-Özmen'in (2006b) yapmış olduğu bir diğer çalışmada zihinsel engelli öğrencilerin yazma sürecinde kullanılan üstbilişsel strateji bilgilerinin geliştirilmesini hedeflediği ve etkili sonuçlar elde ettiği görülmektedir. Güncel bir araştırmada Güler-Bülbül ve Özmen (2021) zihinsel yetersizliği olan öğrencilerin hikaye yazma performanslarını akranların da gözden geçirme aşamasında dahil olduğu bir strateji öğretimi ile çalışmışlardır ve öğrencilerin öykülerinin uzunluk, bütüncül nitelik ve hikaye öğeleri açısından gelişme gösterdiğini belirtmişlerdir. Öğrenme güçlüğü olan öğrencilerin yazılı anlatım performanslarının geliştirilmesine yönelik strateji öğretimi müdahalesi araştırmalarının sınırlı olduğu görülmektedir. Güncel bir araştırmada Ögülmüş (2018) KDSG modeline göre Konu Seç-DüzenleYaz ve Kontrol Et, Karakterler-Ortam-Hedef, Eylem-Sonuç-Durum stratejisinin öğrenme güçlüğü olan öğrencilerin öykü yazma becerilerine etkisini incelemiş ve deney grubu öğrencilerinin sontest puanlarının kontrol grubu öğrencilerine göre anlamlı düzeyde daha yüksek olduğunu, strateji öğretimi müdahalesinin etkili olduğunu belirtmiştir.

\section{Tartışma, Sonuç ve Öneriler}

Öğrenme güçlüğü tanısı almış olan öğrencilerin normal gelişim gösteren akranlarından dil, çalışma belleği, yürütücü işlevler gibi alanlarda farklılık gösterdiği bilinmektedir (Catts, 1993; Stone ve Reid, 1994). Bu bağlamda öğrenme güçlüğü olan öğrenciler için daha açık, basamaklandırılmış öğretimlere ve bu öğretimler sırasında etkili bir şekilde model olunmasına gereksinimleri vardır. Öğrenciye aşamalı olarak sorumluluğun aktarıldığı KDSG öğretim modeli öğrenme güçlüğü olan öğrencilerin öğretim gereksinimlerine uygun bir yöntemdir (Graham ve Perin, 2007). 
Eğitimciler ve aileler, öğrenme güçlüğü olan öğrenciler için yazılı anlatımın zor bir görev olduğunu düşünebilir ve yazılı anlatımın diğer akademik beceriler kadar önemli olmadı̆̆ına inanabilirler. Ayrıca yazılı anlatım üzerindeki müdahalelerin okuma ve anlama becerisini de desteklediği düşünüldüğünde yazılı anlatım çalışmalarının okuma çalışmaları ile birlikte yürütülmesi oldukça önemlidir. Nitekim öğrenciler yazılı anlatım müdahaleleri sırasında stratejik düşünmeyi, bilgiyi düzenlemeyi, plan yapmayı, süreci ve öz düzenleme stratejilerini gözden geçirmeyi öğrenirler ve bu becerileri farklı görevlerde kullanabilirler. Bu kapsamda öğrenme güçlüğü olan öğrenciler, yazılı anlatımlarını nasıl planlayacakları, taslaklarını hazırlayacakları ve gözden geçirecekleri konusunda desteklenmeli ve onlara yazılı anlatımın bir süreç olduğu belirtilmelidir. Elbette bu süreçte ilgileri belirlenerek motivasyon gösterecekleri konularda farklı metin yapılarında yazma çalışmaları yapılması; akıcı yazma, el yazısının niteliği ve karmaşık cümle kurma gibi becerilerinin desteklenmesi yazılı metinlerin niteliğini arttırmaktadır. Etkili bulunmuş stratejilerin öğretiminin yapılmasıyla ve yazma öncesi planlama, planları yazıya geçirme ve metni gözden geçirme aşamalarının öğrencilere kazandırılması ile daha nitelikli yazılı ürünlerin oluşturması olanaklıdır. Bu çalışma ile ebeveynlerin, alanda çalışan öğretmen ve uzmanların öğrenme güçlüğü olan öğrencilerin yazılı anlatım becerilerinin desteklenmesine ilişkin farkındalıklarının arttırılması, bu konuda yapılacak uygulama ve araştırmalara katkı sağlanması amaçlanmıştır.

Yazılı anlatıma yönelik strateji öğretimlerinin yapılması öğrenme güçlüğü olan öğrencilerin daha nitelikli yazılı ürünler oluşturmalarını sağlar. Öğrencilerin yazdıkları metinlerin uzunluklarının artması, metinleri anlamlı paragraflara ayırarak daha iyi düzenlemeleri, anahtar sözcükler kullanarak cümleler arası geçişlerde anlam ilişkilerini daha iyi kurabilmeleri sağlanır. Yapılan öğretimlerin başka alanlarda gösterdiği etkilere bakıldığında da öğrencilerin açık uçlu soruların yer aldığı değerlendirmelerde yanıtlarını daha iyi düzenleyebileceği ve okudukları metinlere yönelik farkındalıklarının artabileceği ve okuduğunu anlama performanslarında olumlu değişimler görülebileceği belirtilebilir.

\section{Kaynakça}

Abbott, R. D., Berninger, V. W., and Fayol, M. (2010). Longitudinal relationships of levels of language in writing and between writing and reading in grades 1 to 7. Journal of Educational Psychology, 102(2), 281-298. https://doi.org/10.1037/a0019318

Baker, S., Gersten, R., and Graham, S. (2003). Teaching expressive writing to students with learning disabilities: Research-based applications and examples. Journal of Learning Disabilities, $36(2), \quad 109-123$. https://doi.org/10.1177/002221940303600204

Bangert-Drowns, R. L., Hurley, M. M., and Wilkinson, B. (2004). The effects of school-based Writing-to-Learn interventions on academic achievement: A metaanalysis. Review of Educational Research, 74(1), 29-58. https://doi.org/10.3102/00346543074001029 
Berninger, V. W., and Amtmann, D. (2003). Preventing written expression disabilities through early and continuing assessment and intervention for hand writing and/or spelling problems: Research into practice. In H. L. Swanson, K. R. Harris, and S. Graham (Eds.), Handbook of learning disabilities (pp. 345-363). New York: The Guilford Press.

Berninger, V. W., Rutberg, J. E., Abbott, R. D., Garcia, N., Anderson-Youngstrom, M., Brooks, A., and Fulton, C. (2006). Tier 1 and Tier 2 early intervention for hand writing and composing. Journal of School Psychology, 44(1), 3-30. https://doi.org/10.1016/j.jsp.2005.12.003

Berry, A. B., and Mason, L. H. (2012). The effects of self-regulated strategy development on the writing of expository essays for adults with written expression difficulties: Preparing for the GED. Remedial and Special Education, 33(2), 124-136. https://doi.org/10.1177/0741932510375469

Cameron, C. A., Hunt, A. K., and Linton, M. J. (1996). Written expression as recontextualization: Children write in social time. Educational Psychology Review, 8(2), 125-150. https://doi.org/10.1007/BF02160677

Catts, H. W. (1993). The relationship between speech-language impairments and reading disabilities. Journal of Speech, Language, and Hearing Research, 36(5), 948-958. https://doi.org/10.1044/jshr.3605.948

Chalk, J. C., Hagan-Burke, S., and Burke, M. D. (2005). The effects of self-regulated strategy development on the writing process for high school students with learning disabilities. Learning Disability Quarterly, 28(1), 175-188. https://doi.org/10.2307/4126974

Cordeiro, C., Castro, S. L., and Limpo, T. (2018). Examining potential sources of gender differences in writing: The role of hand writing fluency and self-efficacy beliefs. Written Communication, 35(4), 448-473. https://doi.org/10.1177/0741088318788843

De La Paz, S. (1999). Self-regulated strategy instruction in regular education settings: Improving outcomes for students with and without learning disabilities. Learning Disabilities Research \& Practice, 14(2), 92-106. https://doi.org/10.1207/sldrp1402_3

Dockrell, J. E., Marshall, C. R., and Wyse, D. (2016). Teachers' reported practices for teaching writing in England. Reading and Writing, 29(3), 409-434. https://doi.org/10.1007/s11145-015-9605-9

Dymock, S. (2005), Teaching expository text structure awareness. The Reading Teacher, 59(2), 177-181. https://doi.org/10.1598/RT.59.2.7

Englert, C. S., and Raphael, T. E. (1988). Constructing well-formed prose: Process, structure, and metacognitive knowledge. Exceptional Children, 54(6), 513-520. https://doi.org/10.1177/001440298805400604 
Englert, C. S., Raphael, T. E., Anderson, L. M., Anthony, H. M., and Stevens, D. D. (1991). Making strategies and self-talk visible: Writing instruction in regular and special education classrooms. American Educational Research Journal, 28(2), 337-372. https://doi.org/10.3102/00028312028002337

Ennis, R. P., Jolivette, K., and Boden, L. J. (2013). STOP and DARE: Self-regulated strategy development for persuasive writing with elementary students with E/BD in a residential facility. Education and Treatment of Children, 36(3), 81-99. https://doi.org/10.1353/etc.2013.0026

Evmenova, A. S., Regan, K., Ahn, S. Y., and Good, K. (2020). Teacher implementation of a technology-based intervention for writing. Learning Disabilities: A Contemporary Journal, 18(1), 27-39. Retrieved from https://eric.ed.gov/?id=EJ1264337

Gersten, R., and Baker, S. (2001). Teaching expressive writing to students with learning disabilities: A meta-analysis. The Elementary School Journal, 101(3), 251-272. https://doi.org/10.1086/499668

Gillespie, A., and Graham, S. (2014). A meta-analysis of writing interventions for students with learning disabilities. Exceptional Children, 80(4), 454-473. https://doi.org/10.1177/0014402914527238

Graham, S. (1990). The role of production factors in learning disabled students' compositions. Journal of Educational Psychology, 82(4), 781-791. https://doi.org/10.1037/0022-0663.82.4.781

Graham, S. (2006). Writing. In P. Alexander and P. Winne (Eds.), Handbook of educational psychology (pp. 457-478). Mahwah, NJ: Erlbaum.

Graham, S., and Harris, K. B. (1992). Cognitive strategy instruction in written language for learning disabled students. In S. A. Vogel (Ed.), Educational alternatives for students with learning disabilities (pp. 91-115). New York: Springer Verlag.

Graham, S., and Harris, K. R. (1997). It can be taught, but it does not develop naturally: Myths and realities in writing instruction. School Psychology Review, 26(3), 414-424. https://doi.org/10.1080/02796015.1997.12085875

Graham, S., and Harris, K. R. (2003). Students with learning disabilities and the process of writing: A metaanalysis of SRSD studies. In H. L. Swanson, K. R. Harris, and S. Graham (Eds.) Handbook of learning disabilities (pp. 323-334). New York: Guilford Press.

Graham, S., and Harris, K. R. (2005a). Improving the writing performance of young struggling writers: The oretical and programmatic research from the center on accelerating student learning. The Journal of Special Education, 39(1), 19-33. https://doi.org/10.1177/00224669050390010301 
Graham, S., and Harris, K. R. (2005b). Writing better: Effective strategies for teaching students with learning disabilities. Baltimore, MD: Paul H. Brookes.

Graham, S., and Hebert, M. (2010). Writing to read: Evidence for how writing can improve reading: A report from Carnegie Corporation of New York. Retrieved from https://acuresearchbank.acu.edu.au/item/8v6x5/writing-to-read-evidencefor-how-writing-can-improve-reading-a-report-from-carnegie-corporation-ofnew-york

Graham, S., and Hebert, M. (2011). Writing to read: A meta-analysis of the impact of writing and writing instruction on reading. Harvard Educational Review, 81(4), 710-744. https://doi.org/10.17763/haer.81.4.t2k0m13756113566

Graham, S., and Perin, D. (2007). A meta-analysis of writing instruction for adolescent students. Journal of Educational Psychology, 99(3), 445-476. https://doi.org/10.1037/0022-0663.99.3.445

Graham, S., Collins, A. A., and Rigby-Wills, H. (2017). Writing characteristics of students with learning disabilities and typically achieving peers: A metaanalysis. $\quad$ ExceptionalChildren, $\quad 83(2), \quad 199-218$. https://doi.org/10.1177/0014402916664070

Graham, S., Fishman, E. J., Reid, R., and Hebert, M. (2016). Writing characteristics of students with attention deficit hyperactive disorder: a meta-analysis. Learning Disabilities Research \& Practice, 31(2), 7589.https://doi.org/10.1111/ldrp.12099

Graham, S., Gillespie, A., and McKeown, D. (2013). Writing: Importance, development, and instruction. Reading and Writing, 26(1), 115.https://doi.org/10.1007/s11145-012-9395-2

Graham, S., Harris, K. R., and Fink, B. (2000). Is handwriting causally related to learning to write? Treatment of handwriting problems in beginning writers. Journal of Educational Psychology, 92(4), 620-633. https://doi.org/10.1037/0022-0663.92.4.620

Graham, S., MacArthur, C. A., and Fitzgerald, J. (2007). Best practices in writing instruction. New York: Guilford Press.

Graham, S., McKeown, D., Kiuhara, S., and Harris, K. R. (2012). A meta-analysis of writing instruction for students in the elementary grades. Journal of Educational Psychology, 104(4), 879-896. https://doi.org/10.1037/a0029185

Graham, S., Schwartz, S. S., and MacArthur, C. A. (1993). Knowledge of writing and the composing process, attitude toward writing, and self-efficacy for students with and without learning disabilities. Journal of Learning Disabilities, 26(4), 237-249. https://doi.org/10.1177/002221949302600404 
Güler-Bülbül, Ö., and Özmen, E. R. (2021). Effectiveness of teaching story-writing strategy to students with intellectual disabilities and their non-disabled peers. Journal of Intellectual \& Developmental Disability, 46(3), 204-2016. https://doi.org/10.3109/13668250.2019.1698286

Güzel-Özmen, E. R. (2006a). The effectiveness of modified cognitive strategy instruction in writing with mildly mentally retarded Turkish students. ExceptionalChildren, 72(3), 281-297. https://doi.org/10.1177/001440290607200302

Güzel-Özmen, E. R. (2006b). Uyarlanmış bilişsel strateji öğretiminin zihinsel engelli öğrencilerin yazılı ifade sürecinde kullanılan üstbilişsel strateji bilgisini kazanmalarında etkisi. Ankara Üniversitesi Eğitim Bilimleri Fakültesi Özel Ĕgitim Dergisi, 7(2), 49-66. https://doi.org/10.1501/Ozlegt_0000000101

Harris, K. R., and Graham, S. (2013). An adjective is a word hanging down from a noun: Learning to write and students with learning disabilities. Annals of Dyslexia, 63, 65-79. https://doi.org/10.1007/s11881-011-0057-x

Harris, K. R., Graham, S., and Mason, L. H. (2003). Self-regulated strategy development in theclassroom: Part of a balanced approach to writing instruction for students with disabilities. Focus on Exceptional Children, 35(7), 1-16. Retrieved from https://eric.ed.gov/?id=EJ679488

Harris, K. R., Graham, S., and Mason, L. H. (2006). Improving the writing, knowledge, and motivation of struggling young writers: Effects of self-regulated strategy development with and without peer support. American Educational Research Journal, 43(2), 295-340. https://doi.org/10.3102/00028312043002295

Harris, K. R., Graham, S., Friedlander, B., and Laud, L. (2013). Bring powerful writing strategies into your classroom! Why and how. The Reading Teacher, 66(7), 538-542. https://doi.org/10.1002/TRTR.1156

Hayes, J. (1996). A new framework for understanding cognition and affect in writing. In M. Levyand and S. Ransdell (Eds.), Thescience of writing: Theories, methods, individual differences, andapplications (pp. 1-27). Mahwah, NJ: Erbaum.

Hayes, J., and Flower, L. (1980). Identifying the organization of writing process. In L. Greggand and E. Steinberg (Eds.), Cognitive processes in writing (pp. 3-30). Hillsdale, NJ: Erlbaum.

Hooper, S. R., Swartz, C. W., Wakely, M. B., de Kruif, R. E., and Montgomery, J. W. (2002). Executive functions in elementary school children with and without problems in written expression. Journal of Learning Disabilities, 35(1), 57-68. https://doi.org/10.1177/002221940203500105

MacArthur, C. A. (2007). Best practices in teaching evaluation and revision. In S. Graham, C. A. Mac-Arthur, and J. Fitzgerald (Eds.), Best practices in writing instruction (pp. 141-162). New York: Guilford. 
MacArthur, C. A., and Graham, S. (1987). Learning disabled students' composing under three methods of text production: Handwriting, wordprocessing, and dictation. The Journal of Special Education, 21(3), 22-42. https://doi.org/10.1177/002246698702100304

MacArthur, C. A., and Philippakos, Z. (2010). Instruction in a strategy for comparecontrast writing. Exceptional Children, 76(4), 438-456. https://doi.org/10.1177/001440291007600404

MacArthur, C. A., Graham, S., and Schwartz, S. (1991). Knowledge of revision and revising behavior among students with learning disabilities. Learning Disability Quarterly, 14(1), 61-73. https://doi.org/10.2307/1510373

Mason, L. H., Snyder, K. H., Sukhram, D. P., and Kedem, Y. (2006). TWA+PLANS strategies for expository reading and writing: Effects for nine fourth-grade students. Exceptional Children, 73(1), 69-89. https://doi.org/10.1177/001440290607300104

Milli Eğitim Bakanlığı (2019). Türkçe dersi öğretim programı ilkokul ve ortaokul 1,2,3,4,5,6,7 ve 8 . https://mufredat.meb.gov.tr/ProgramDetay.aspx?PID=663 adresinden erişilmiştir.

Montague, M., Graves, A., and Leavell, A. (1991). Planning, procedural facilitation, and narrative composition of junior high students with learning disabilities. Learning Disabilities Research \& Practice, 6(4), 219-224. Retrieved from https://eric.ed.gov/?id=EJ437760

Öğülmüş, K. (2018). Öz düzenlemeli strateji geliştirme modeli temelinde şekillendirilen ögretim paketinin özel ögrenme güçlüğü olan ögrencilerin öykü yazma becerilerine etkisi (Yayımlanmamış doktora tezi). Eskişehir Osmangazi Üniversitesi, Eğitim Bilimleri Enstitüsü, Eskişehir.

Özbek, A. B., Kılıç-Tülü, B., and Ergül, C. (2019). An intervention to improve the writing skills of students with learning disabilities: Stop \& List Strategy. Insights into Learning Disabilities, 16(2), 155-171. Retrieved from https://eric.ed.gov/?id=EJ1241253

Özmen, E. R., Selimoğlu, Ö. G. ve Şimşek, M. Ö. (2015). Uyarlanmış bilişsel strateji öğretiminin öykü yazmada uygulanması: Zihinsel yetersizliği olan bir öğrenci ile vaka çalışması. Ankara Üniversitesi Eğitim Bilimleri Fakültesi Özel Eğitim Dergisi, 16(2), 149-164. https://doi.org/10.1501/Ozlegt_0000000225

Öztürk, H. ve Girli, A. (2017). Özel öğrenme güçlüğünde yazılı anlatım ve yazma kaygısı. Uluslararası Sosyal Araştırmalar Dergisi, 10(51), 784-794. https://doi.org/10.17719/jisr.2017.1815 
Öztürk, H. ve Girli, A. (2018). Özel öğrenme güçlüğü tanılı öğrencilerin yazılı anlatım düzeyleri. Uluslararası Karamanoğlu Mehmetbey Eğitim Araştırmaları Dergisi, 2(1), 35-47. https://dergipark.org.tr/tr/pub/ukmead/issue/55651/694824 adresinden erişilmiştir.

Pyle N., Vasquez, A. C., Lignugaris-Kraft, B., Gillam, S. L., Reutzel, D. R., Olszewski, ..., and Pyle, D. (2017). Effects of expository text structure interventions on comprehension: A meta-analysis. Reading Research Quarterly, 52(4), 469-501. https://doi.org/10.1002/rrq.179

Reid, R., and Lienemann, T. O. (2006). Self-regulated strategy development for written expression with students with attention deficit/hyperactivity disorder. Exceptional Children, 73(1), 53-68. https://doi.org/10.1177/001440290607300103

Russell, D. (1997). Rethinking genre in school and society: An activity theory analysis. Written Communication, 14(4), 504-554. https://doi.org/10.1177/0741088397014004004

Saddler, B. (2006). Increasing story-writing ability through self-regulated strategy development: Effects on young writers with learning disabilities. Learning Disability Quarterly, 29(4), 291-305. https://doi.org/10.2307/30035555

Seban, D. (2008). Öğretmenlerin yazılı anlatım öğretimi hakkındaki inanç ve uygulamalarına durum çalışmaları üzerinden bir bakış. Elementary Education Online, $\quad 7(2), \quad 512-521 . \quad$ https://www.ilkogretim-online.org/?mno=121484 adresinden erişilmiştir.

Shen, M., and Troia, G. A. (2018). Teaching children with language-learning disabilities to plan and revise compare-contrast texts. Learning Disability Quarterly, 41(1), 44-61. https://doi.org/10.1177/0731948717701260

Stone, C. A., and Reid, D. K. (1994). Social and individual forces in learning: Implications for instruction of children with learning difficulties. Learning Disability Quarterly, 17(1), 72-86. https://doi.org/10.2307/1511106

Taft, R., and Mason, L. (2011). Examining effects of writing interventions: Highlighting results for students with primary disabilities other than learning disabilities. Remedial and Special Education, 32(5), 359-370. https://doi.org/10.1177/0741932510362242

Thoennes, S. A. (2016) Effective writing interventions for students with learning disabilities (Unpublished masters thesis). St. Cloud State University, St. Cloud.

Troia, G. A. (2006). Writing instruction for students with learning disabilities. In C. A. MacArthur, S. Graham, and J. Fitzgerald (Eds.), Handbook of writing research (pp. 324-336). New York: Guilford Press. 
Troia, G. A., Brehmer, J. S., Glause, K., Reichmuth, H. L., and Lawrence, F. (2020). Direct and indirect effects of literacy skills and writing fluency on writing quality across three genres. Education Sciences, 10(297), 1-21. https://doi.org/10.3390/educsci10110297

Troia, G. A., Harbaugh, A. G. Shankland, R. K., Wolbers, K. A.,and Lawrence, A. M. (2017). Relationships between writing motivation, writing activity, and writing performance: Effects of grade, sex, and ability, Reading and Writing, 26(1), 1744. https://doi.org/10.1007/s11145-012-9379-2

Welch, M. (1992). The PLEASE strategy: A metacognitive learning strategy for improving the paragraph writing of students with mild learning disabilities. Learning Disability Quarterly, 15(2), 119-128. https://doi.org/10.2307/1511013

Williams, J. P., Hall, K. M., and Lauer, K. D. (2004). Teaching expository text structure to young at-risk learners: Building the basics of comprehension instruction. $\quad$ Exceptionality, 12(3), 129-144. https://doi.org/10.1207/s15327035ex1203_2

Wong, B. Y. L., Butler, D. L., Ficzere, S. A., and Kuperis, S. (1996). Teaching low achievers and students with learning disabilities to plan, write, and revise opinion essays. Journal of Learning Disabilities, 29(2), 197-212. https://doi.org/10.1177/002221949602900209

Zimmerman, B. J., and Risemberg, R. (1997). Becoming a self-regulated writer: A social cognitive perspective. Contemporary Educational Psychology, 22(1), 73 101. https://doi.org/10.1006/ceps.1997.0919

\section{Etik Kurul Kararı}

$\mathrm{Bu}$ araştırma, derleme türünde makale olduğu için etik kurul kararı gerektirmemektedir. 


\section{Ek. KDSG Öğretim Modeline Yürütülen Dur-Düşün-Listele Yazma Stratejisi Öğretimi Örneği}

\section{Oturum Önceki Bilgiyi Geliştirme ve Etkinleștirme}

Çalışmanın başında öğrenci ile yazma süreci, metinlerin nasıl yazıldığı hakkında konuşulmuştur ve yazma deneyimleri öğrenilmiştir. "Kaan okulda öğretmenin senden bir konu hakkında yazı yazmanızı istedi mi? Peki ben geçen dersimizde senden bir metin yazmanı istediğimde nasıl bir yol izledin? Yazarken neye ihtiyaç duydun? Okuduğumuz kitaplardaki metinler nasıl yazılıyor acaba, yazarlar kitaplarını nasıl yazıyorlar hiç düşündün mü?” gibi sorularla öğrencilerin yazma becerisi hakkındaki ön bilgileri etkin hale getirilmeye çalışılmıştır.

\section{Oturum Tartışma}

Tartışma aşamasında öğrenciye iyi yazılmış bir tanımsal metin gösterilerek metni okuması istenmiştir. Metnin bölümleri, tanıtılan konunun özelliklerinin nasıl yer aldığı, anahtar sözcükler ve metnin paragraflara nasıl ayırıldığ 1 örnek gösterilerek açıklanmıştır.Öğrenci ile iyi yazılmış metinler yazmak için neler yapılabileceği üzerine konuşulur. Öğrenciye Dur-Düşün-Listele stratejisi çalışma kağıtları kullanılarak açıklanmıştır. Öğrenciye çalışmada kullanılacak olan planlama ve çalışma kağıdı tanıtılarak bu araçların nasıl kullanılacağı, yazma sürecinde öğrenciye nasıl yardımcı olacakları anlatılmıştır. "Buse bak bu çalışmamızda bu iki çalışma kağıdını kullanacă̆ız. Bu bizim planlama kağıdımız. Yazdığımız konu hakkında bildiklerimizi buraya yazacağız. Aklımıza gelenfikirleri bu kağıt üzerinde gruplayıp ardından paragraflara dönüştüreceğiz. Bunu yaparken de anahtar sözcüklerimizden yararlanacağız. Yazmak istediğimiz konuyu seçip, durup, düşünüp aklımıza gelenleri liste yapacağız." şeklinde öğrenciye süreç açıklanmıştır.

\section{Oturum Model Olma}

Öğrencinin ilgi duyduğu ve hakkında bilgi sahibi olduğu konulardan biri seçilerek öğretim sürecine başlanmıştır. Bu aşamada planlama ve çalışma kağıtlarının birer kopyası öğrenci ve uygulayıcının önünde duracak şekilde yan yana oturulmuştur. Öğrenciye planlama ve çalışma kağıdının nasıl kullanılacağı açıklanmıştır. "Evet, konumuzu seçtik;badmington hakkında bir yazı yazacağız. Badmington sporunu hiç bilmeyen birisi okuduğunda nasıl bir spor olduğunu öğrenecek. Stratejimizin adımları neydi? Durdum! Bu sporun özellikleri neler hadi beraber düşünelim? Düşün.” şeklinde uygulamacı öğrenciye model olmuştur. Bu aşamayı kolaylaştırmak için planlama kağıdının sol tarafına yerleştirilen sütunda "Nedir? Nasıl? Kaç? Nerede? Kim?" gibi konuya uygun öğrencinin konuya ilişkin bilgilerini hatırlaması için ipuçları bulunmaktadır. "Badmington nasıl oynanır?" gibi örnek bir soru sorularak öğrencininfikirleriplanlama kağıdına yazılmıştır. "Şimdi de Listele basamağı... DurDüşün-Listele...Fikirlerimizi listeliyoruz." $\mathrm{Bu}$ aşamada uygulamacı da kendi planlama kağıdı üzerine öğrenci ile ürettikleri fikirleri not almıştır. Uygulamacı, öğrenciyi yönlendirerek konu hakkında tüm soruları sorarak yanıtları planlama kağıdında ilişkili olduğu bilgilerin olduğu bölüme yazmasını sağlamıştır. Ardından öğrenci ile metinde hangi özelliklerin önce, hangi özelliklerin sonra yazılacağına karar 
verilmiştir. "Aklımıza gelenleri, fikirlerimizi listeledik. Şimdi bunları hangi sırada yazacağımızı düşünelim, her gruba numara verelim." diyerek planlama kağıdındaki tüm kutucuklar numaralandırılmış ve yazma aşamasına geçilmiştir. Yazma aşaması için çalışma kağıtları kullanılmıştır. Yazma sürecinde çalışma kağıdı üzerinde bulunan "Ayrıca bir diğer özelliği de" gibi anahtar sözcüklerden yararlanılmıştır. Uygulamacı ve öğrenci planlama kağıdında yer alan bilgileri sırasıyla paragraflar olarak çalışma kağıdına aktarmışlardır. Örneğin "Bu kutucukta raket, file, top, iki kişi yazıyor, burası badmington nasıl oynanır bölümü. Bunu nasıl yazalım? Sen ne dersin? Bir cümle kur bakalım... Badmington oynamak için iki raket, top ve file gerekir diyebiliriz. Bak yanda güzel sözcüklerimiz var. Uygun olanları kullanabiliriz.” Bu şekilde tüm kutucuklar anahtar sözcükler de kullanılarak paragraflar halinde yazılmıştır. Öncelikle öğrencinin cümle oluşturması beklenmiş ve öğrencinin söylediği cümleler uygulamacı tarafından düzeltilmiştir. Gerekli durumlarda öğrencinin anahtar sözcükleri kullanımı desteklenmiştir. Son olarak yazma işlemi bittikten sonra öğrenci ile birlikte metin okunmuştur.

\section{Oturum Destekleme}

Öğrenci yazma sürecinin basamakları çalışılırken etkin hale geldikçe uygulamacı desteğini geri çekmeye başlamıştır. Model olma aşamasında tüm araçlardan ikişer adet kullanılırken destekleme aşamasına geçildiğinde yalnızca öğrenci için planlama ve çalışma kağıtları kullanılmıştır. Uygulamacı aşamalı olarak yazma sürecinin sorumluluğunu öğrenciye aktarmıştır. "Stratejimizin adımları nelerdi? Şimdi ne yapmamız gerekiyor? Cümlemiz nasıl daha güzel olur? Yeni bir paragrafa $\mathrm{m} ı$ geçmeliyiz? Bütün fikirleri yazdık mı?” şeklinde sorularla gerekli durumlarda öğrenciye ipuçları verilerek yönlendirmeler yapılmıştır. Her oturum sonunda öğrenci ile birlikte metin okunmuştur.

\section{Oturum Bağımsız Uygulama}

$\mathrm{Bu}$ aşamada öğrenciler ile bağımsız uygulamalar denenmiştir. Çalışma ve planlama kağıtları ortamdan tamamen çıkarılmış, öğrencilere yalnızca boş kağıtlar verilerek konu listesinden seçtiği bir konu hakkında tanımsal metin yazması istenmiştir. Öğrencinin uzun süre beklediği durumlarda sürece devam etmesini sağlamak amacıyla "Şimdi ne yapman gerekiyor? Nasıl planlama yapıyorduk?" gibi ipuçları verilerek sürece devam etmesi sağlanmıştır. 


\title{
Supporting Written Expression Skills of Students with Learning Disabilities: Strategy Instruction
}

\begin{tabular}{cccc}
\hline ARTICLE TYPE & Received Date & Accepted Date & Published Date \\
Review Article & 01.12 .2021 & 09.21 .2021 & 10.04 .2021 \\
\hline
\end{tabular}
A. Bilal Özbek
Dokuz Eylül University

Burcu Kılıç Tülü (iD)
Ankara University

\begin{abstract}
Written expression is one of the highest achievements of literacy. During the writing process students should use their background knowledge, experiences and imagination to become productive and write them in an organization according to a text structure. Many different cognitive skills are required to use actively during writing a text. Students with learning disabilities experience difficulties in writing. Studies conducted with learning disabilities show there are fewer studies on written expression skills than other academic skills such as reading fluency and reading comprehension. The aim of this review study is to describe the difficulties students with learning disabilities experience in written expression, explaining the reasons behind those difficulties, emphasizing the importance of written expression skills and giving examples of effective strategy instruction methods towards writing skills. Strategy instruction aims to develop the writing skills of students during the planning, writing and revising phases of written expression process. Significant improvements have seen in studies conducting strategy instruction according to the SRSD teaching model which presents opportunities for frequent practice and explicit modeling to students with learning disabilities.It is possible to teach how to write more qualified written products by teaching effective strategies according to the phases of the writing process. With this study, it is aimed to increase the awareness of parents, teachers and experts working in the field about supporting the written expression skills of students with learning disabilities and to contribute to the education of children.
\end{abstract}

Keywords: Writing, written expression, strategy instruction, metacognitive strategies, learning disabilities.

The ethical committee approval: Since this research is a review article, it does not require an ethics committee decision.

${ }^{1}$ Corresponding Author: Dr., Buca Faculty of Education, Special Education Department, e-mail: bilal.ozbek@deu.edu.tr, https://orcid.org/0000-0002-0200-4932

${ }^{2}$ Dr., Faculty of Educational Science, Special Education Department, e-mail: burcukilic2012@hotmail.com, https://orcid.org/0000-0002-9623-8392 
Written expression is an indispensable tool of learning and communication that affects people's thoughts (Bangert-Drowns, Hurley and Wilkinson, 2004; Graham, 2006). Written expression is a complex process that involves basic writing skills, writing and reading fluency, reading comprehension, background knowledge, generating and organizing ideas (Graham, 2006). Additionally, written expression is frequently used in assessments of academic achievements and students are expected to write well-organized holistic answers that reflect their information about the topic (Graham, MacArthur and Fitzgerald, 2007). It was seen that students' summarizing, note-taking, question generation skills support their retell performances (Graham and Hebert, 2011).

Written expression becomes important, especially after third grade when students begin to use writing skills as a tool to show their knowledge, thoughts and experiences. In primary and secondary school curriculums there are educational goals that students are expected to create written products in accordance with spelling, punctuation and grammar rules, according to a specific purpose and audience, and in different types (Ministry of National Education [Milli Eğitim Bakanlı̆̆1-MEB], 2019). Students are required to actively use their writing skills both in evaluations of the written expression goals in the curriculum and in the exams of other courses. In these assesments, many typically developing students experience difficulties as their peers with learning disabilities (LD peers). In the National Assessment of Educational Progress (NAEP) report, it is stated that only $6 \%$ of LD students have adequate writing skills (Graham and Perin, 2007). Considering the curriculum and class activities there is a discrepancy between the time many educators use to support students' writing skills and the emphasis on written expression in the curriculum (Graham and Harris, 1997). Especially, as the time allocated to supporting reading fluency and reading comprehension skills increases, writing skills move away from the focus of teaching and less time is allocated for this skill (Baker, Gersten and Graham 2003).

\section{Learning Disabilities and Written Expression}

Students with learning disabilities have limited information and skills for effective written expression (MacArthur, 2007; MacArthur, Graham and Schwartz, 1991). Studies have shown that compared to their typically developing students with learning disabilities experience much more difficulties in tasks related to writing (Graham, Schwartz and MacArthur, 1993; Reid and Lienemann, 2006; Thoennes, 2016). LD students show lower performances than their peers in written products quality, planning skills, vocabulary, sentence structure, grammar, handwriting and motivation (Graham, Collins and Rigby-Wills, 2017; Öztürk and Girli, 2017). Especially LD students have deficits in self-regulation and flexible thinking (Hooper, Swartz, Wakely, de Kruif and Montgomery, 2002). As a result of these deficits their written texts' persuasiveness and overall quality significantly low. In order to write texts that convince the reader, they need to be able to see different perspectives and produce reasons that can support their own ideas. In summary, students with LD show poorer performance in writing skills than their typically developing peers (Gersten and Baker, 2001). 


\section{Supporting Written Expression Performances of Students with LD with Strategy Instruction}

Traditionally, teachers give verbal instructions and explain the characteristics of a well-written text to develop the written expression skills of students with learning difficulties. These interventions have a limited impact on students' performances. Because of this, interventions that which include explicit instruction and create much more practice opportunities should be used (Graham and Harris, 2003). In metaanalysis studies, researchers identified some effective methods in increasing the quality of written products of students from different grade levels. These methods are strategy instruction, cooperative writing, pre-writing preparations, summarizing, sentence structure, text structure instruction, teaching transcription skills, revising and giving additional time for writing (Bangert-Drowns, et al., 2004; Graham and Perin, 2007). One of these methods, strategy instruction, is an effective method that is frequently used with students who have LD Strategy instruction can focus on planning, writing and revising phases of written expression one at a time or all of them in a holistic way. Managing written expression phases holistically and use strategies independently carry great importance for written expression and students with LD need support to acquire these skills (Cameron, Hunt and Linton, 1996). Working with a teacher or an adult who can respond appropriately to social interaction needs is critical for the development of the written expression skills of students with LD It is necessary to contribute to the development of written expression by introducing students to various writing genres, supporting their language development and providing opportunities to gain writing experiences. Motivation is a very important factor that effects the success of writing instructions. For this reason, it is important to include students' interests and topics they are willing to talk about in writing activities.

Students with learning disabilities need to master the planning, writing and revising phases of the writing process in order to improve their written expression skills and to increase the quality of their written products. It is seen that strategy instruction is a frequently chosen method in studies to improve written expression performances of students with LD over two decades (Berry and Mason, 2012; Evmenova, Regan, Ahn and Good, 2020; Graham and Hebert, 2010; Özbek, KılıçTülü and Ergül, 2019). Strategy instructions are used at different grade levels, various diagnostic groups and different text types (Güzel-Özmen, 2006a; Güzel-Özmen, 2006b; Özmen, Selimoğlu and Şimşek, 2015). It is aimed to teach students planning, generating and organizing ideas, creating paragraphs, revising and editing their texts by using mnemonics of strategies, scaffoldings, and to help students internalize the use of strategies. Studies show that strategy interventions towards writing performances are effective(Graham and Hebert, 2011).

Strategy instruction studies in written expression are examined and it is seen that there are holistic strategies including all phases of the writing process (planning, writing and review) as well as process-based strategies focusing on one or two phases of writing. POWER strategy instruction model (Englert, Raphael, Anderson, Anthony 
and Stevens, 1991) is one of the holistic approaches. In this model, every letter stands for a task students should complete and includes all phases of the writing process (Plan, Organize, Write, Edit, Revise). On the other hand, there are many different process-based strategy interventions as follows: STOP and LIST (Graham and Harris, 2005a; Özbek et al., 2019), STOP and DARE (Ennis, Jolivette and Boden, 2013), POW and TREE (Berry and Mason, 2012), PLEASE (Welch, 1992). The common point of many of these strategies is that they involve the planning phase. It is seen that process-based strategy intervention studies are mostly conducted according to SelfRegulation Strategies Development (SRSD) model (Graham and Harris, 2003)

Harris, Graham, and Mason (2003) stated that a good teaching model should be effective, systematic, and economical in terms of time and energy, a process of 8-12 sessions of 30-40 minutes in total for teaching a strategy is sufficient. Theaim of strategy instructions in the SRSD model is developing students' background knowledge of written expression, teaching them strategies to complete writing tasks and increase their motivation for writing (Graham and Harris, 2005b). In the studies writing strategies conducted according to the SRSD model, it is seen that interventions improve students' written expression performance, students spend more time for planning and writing, increase the overall quality of the texts they produce, and write longer texts (Berry and Mason, 2012; De La Paz, 1999; Harris Graham, and Mason, 2006; MacArthur and Philippakos; 2010, Özbek et al., 2019). In meta-analysis studies examining the results of written expression researches, it is stated that strategy instruction conducted according to the SRSD model has a significant effect on written expression (Gillespie and Graham, 2014; Graham and Perin, 2007; Graham, Fishman, Reid and Hebert, 2016; Taft and Mason, 2011).

\section{Discussion, Conclusion and Suggestions}

Students with learning disabilities show differences from their typically developing peers in language development, working memory and executive functions (Catts, 1993; Stone and Reid, 1994). Therefore students with LD require explicit, gradual teaching and effective models during these interventions. In this context, it can be said that SRSD method is a good alternative for teachers to use in lessons (Graham and Perrin, 2007) and there many different strategy options for different genres and text structures.

The aim of this review is to increase the awareness of parents, teachers and experts working in the field about supporting the written expression skills of students with learning difficulties and present effective examples of interventions. Written expression is a skill that can be learned and developed. Students with learning disabilities should be supported and taught how to plan, create a draft and revise. Additionally writing fluency, handwriting, sentence and paragraph creation skills of students should be supported to increase text quality. students with learning disabilities can create more qualified written products by learning strategies for planning, writing and revising. 
Writing and reading skills can be developed together in a holistic approach. Making reading fluency and reading comprehension a priority of educational support often ends with neglecting writing skills. However, it is known that interventions on written expression support reading skills too. Educators and families may think that written expression is a challenging task for students with learning disabilities and they may believe learning writing strategies doesn't carry importance as solving math problems and reading comprehension. However students learn strategic thinking, organizing information, making plans, revising the process and self-regulation strategies during written expression interventions, and they can use these skills in different tasks.

\section{The Ethical Committee Approval}

Since this research is a review article, it does not require an ethics committee decision. 